\title{
Petrophysical characterization for Thebes and Mutulla reservoirs in Rabeh East Field, Gulf of Suez Basin, via well logging interpretation
}

\author{
Mohammad Abdelfattah Sarhan ${ }^{1}$ (D)
}

Received: 13 July 2021 / Accepted: 30 August 2021 / Published online: 6 September 2021

(c) The Author(s) 2021

\begin{abstract}
The current work assesses the sandstones of the Mutulla Formation as well as the limestone of the Thebes Formation for being promising new oil reservoirs in Rabeh East field at the southern portion of the Gulf of Suez Basin. This assessment has been achieved through petrophysical evaluation of wireline logs for three wells (RE-8, RE-22 and RE-25). The visual analysis of well logs data revealed that RE-25 Well is the only well demonstrating positive criteria in five zones for being potential oil reservoirs. The favourable zone within Thebes Formation locates between depths $5084 \mathrm{ft}$ and $5100 \mathrm{ft}$ (Zone A). However, the other positive zones in Mutulla Formation occur between depths: 5403.5-5413.5 ft (Zone B), 5425.5-5436 ft (Zone C), $5488-5498 \mathrm{ft}$ (Zone D) and 5558.5-5563.5 ft (Zone E). The quantitative evaluation shows that the Zone A of Thebes Formation is the best oil-bearing zone in RE-25 Well in terms of reservoir quality since it exhibits lowest shale volume (0.07), minimum water saturation $(0.23)$ and lowest bulk volume of water (0.03). These limestone beds include type of secondary porosity beside the existing primary porosity. On the other hand, the sandstones of Mutulla Formation in RE- 25 contain four reservoir zones (B, C, D and E) with the total net pay thickness of $35.5 \mathrm{ft}$. Moreover, the obtained results revealed that it is expected for zones B, C and D to produce oil without water but Zone E will produce oil with water.
\end{abstract}

Keywords Petrophysical characterization · Rabeh East field · Thebes Formation · Mutulla Formation · Gulf of Suez Basin

\section{Introduction}

The Gulf of Suez Basin (GSB) province is the oldest and the most productive oil region in Egypt. It represents an intercontinental rift extending for about $325 \mathrm{~km}$ northward from Hurghada city in the south (El Nady et al. 2016). Despite the fact that its rifting process began in the Miocene epoch, both post-rift and pre-rift periods contain prospective source rocks and reservoirs (Shahin and Shehab 1984; EGPC, 1996; Atta et al. 2002).

The GSB encompasses more than 80 fields producing oil from Precambrian to Tertiary reservoirs. Due to the large amounts of exploration data as well as the existence of wellexposed syn-rift strata, numerous geological studies covering the evolution of the GSB rifting have been carried out (e.g. Winn et al. 2001; Alsharhan 2003; El Nady et al. 2015;

Mohammad Abdelfattah Sarhan msarhan@du.edu.eg

1 Geology Department, Damietta University, New Damietta City 34517, Egypt
Radwan, et al. 2020; Moustafa and Khalil 2020; Radwan and Sen 2021; Radwan 2021a,b; Radwan et al. 2021a,b,c).

The rifting fault blocks are the main hydrocarbon traps within the GSB oil fields (Sultan 2002; Chowdhary and Taha 1987). The Miocene clastics hold nearly $60 \%$ of oil reserves in the GSB, and the residual is frequently existing in the PreCenomanian Nubia sandstones (Peijs et al. 2012).

Rabeh East field is located between longitudes: $33^{\circ} 39^{\prime}$ $16.8^{\prime \prime} \mathrm{E}, 33^{\circ} 47^{\prime} 56.1^{\prime \prime} \mathrm{E}$ and latitudes: $27^{\circ} 9^{\prime} 36.3^{\prime \prime} \mathrm{N}, 27^{\circ}$ $17^{\prime} 0.7^{\prime \prime} \mathrm{N}$ at the southern portion of the GSB (Fig. 1). The sandstones of Nubia and Nukhul formations as well as the carbonates of Rudies Formation exhibit the essential targets for oil production at Rabeh East oil field (Sarhan and Basal 2019; Sarhan 2020, 2021).

Consequently, the present work aims to perform geophysical assessment using well log data for the limestone of Thebes Formation and the sandstones of Mutulla Formation in order to add new promising targets to the well-known oil reservoirs in Rabeh East field. 


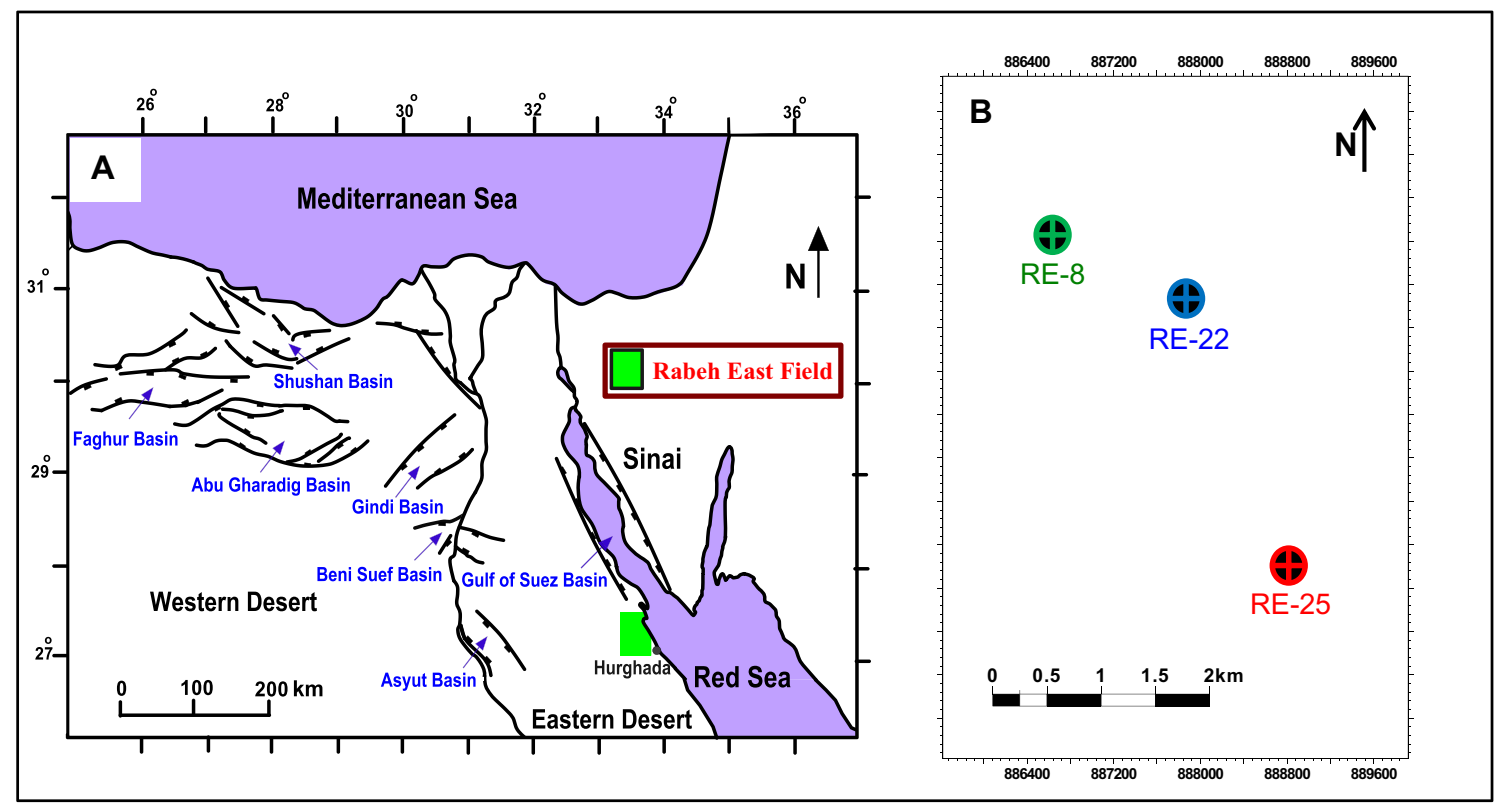

Fig. 1 a Regional map shows the location of Rabeh East Field at the southern GSB. b Study area with well locations

\section{Geological setting}

The rifting of the GSB started through the Early Miocene age because of the divergence between the African plate and the Arabian plate, which led to forming a series of extensional faults trending NW-SE to NNW-SSE (Bosworth et al. 2005; Patton et al. 1994). These fault arrays moved to the north-west and affected the Late Miocene sequence beneath the Nile Delta area (Sarhan et al. 2014).

The structural and depositional setting of the GSB is complex due to the superimposing of the rifting-related faults with the pre-rift structures (Abul Karamat and Meshref 2002). The faulted blocks of the GSB are bounded principally by NW extensional faults, which are linked to each other by WNW-, NNE- and NE-oriented faults (AbdAllah et al. 2014).

The lithostratigraphy of the GSB including Rabeh East Field starts with the clastics of Nubia Formation, which are overlain by the Matulla, Duwi and Sudr formations. These units are topped by Esna Shale Formation (Palaeocene) and then the Thebes Formation (Eocene). The Miocene stratigraphy comprises: Nukhul, Rudeis, Kareem, Belayim, South Gharib and Zeit formations, respectively, from base to top (Fig. 2).

Based on the available wells in Rabeh East Field, the Eocene Thebes Formation is mainly composed of limestones (Fig. 3), whereas the Matulla Formation consists principally of sandstones and shale interbeds (Fig. 4).

The limestone of Thebes Formation was deposited during the Tethyan major transgression over the north-east of
Africa in the Eocene times. This limestone characterises a potential source rock with TOC equal to $3.2 \%$ of type I/ II kerogens; however, the generated hydrocarbon has low API gravity, high sulphur content and high HI and low OI values (Alsharhan 2003). The fractured limestones of the Thebes Formation provide around $1.1 \%$ of oil production in the GSB with $13 \%$ average porosity, and net pay thickness varies between 15 and $17 \mathrm{~m}$. Numerous fields, such as Sudr, Asal, Kareem, Ras Matarma, Bakr, West Bakr, Ali, Issaran, Shoab and Rahmi, produce oil from the entire carbonates of Thebes Formation (Alsharhan 2003).

The Matulla Formation is separated between the overlain Brown limestone Formation and the underlain Wata Formation by two unconformity surfaces. The entire clastics of the Matulla Formation were deposited throughout the Coniacian-Santonian time span. A diverse planktonic foraminiferal content including Dicarinella concavata and D. asymetrica zones revealing the Coniacian-Santonian age characterizes the Matulla Formation (Alsharhan 2003).

The Matulla Formation represents a complete third-order depositional sequence that embraces the Coniacian-Santonian interval and is subdivided into LST, TST and HST system tracts. This sequence was deposited through a reduction in the accommodation space towards the inner shelf water depth, resulting in the sedimentation of the lowest part of Matulla Formation as lowstand system tracts (LSTs). This step was followed by a transgressive stage within a relatively deeper marine setting (outer shelf conditions), resulting in the deposition of the middle part of the Matulla Formation as transgressive system tracts (TSTs). The deposition of the uppermost parts of the Matulla Formation as highstand 


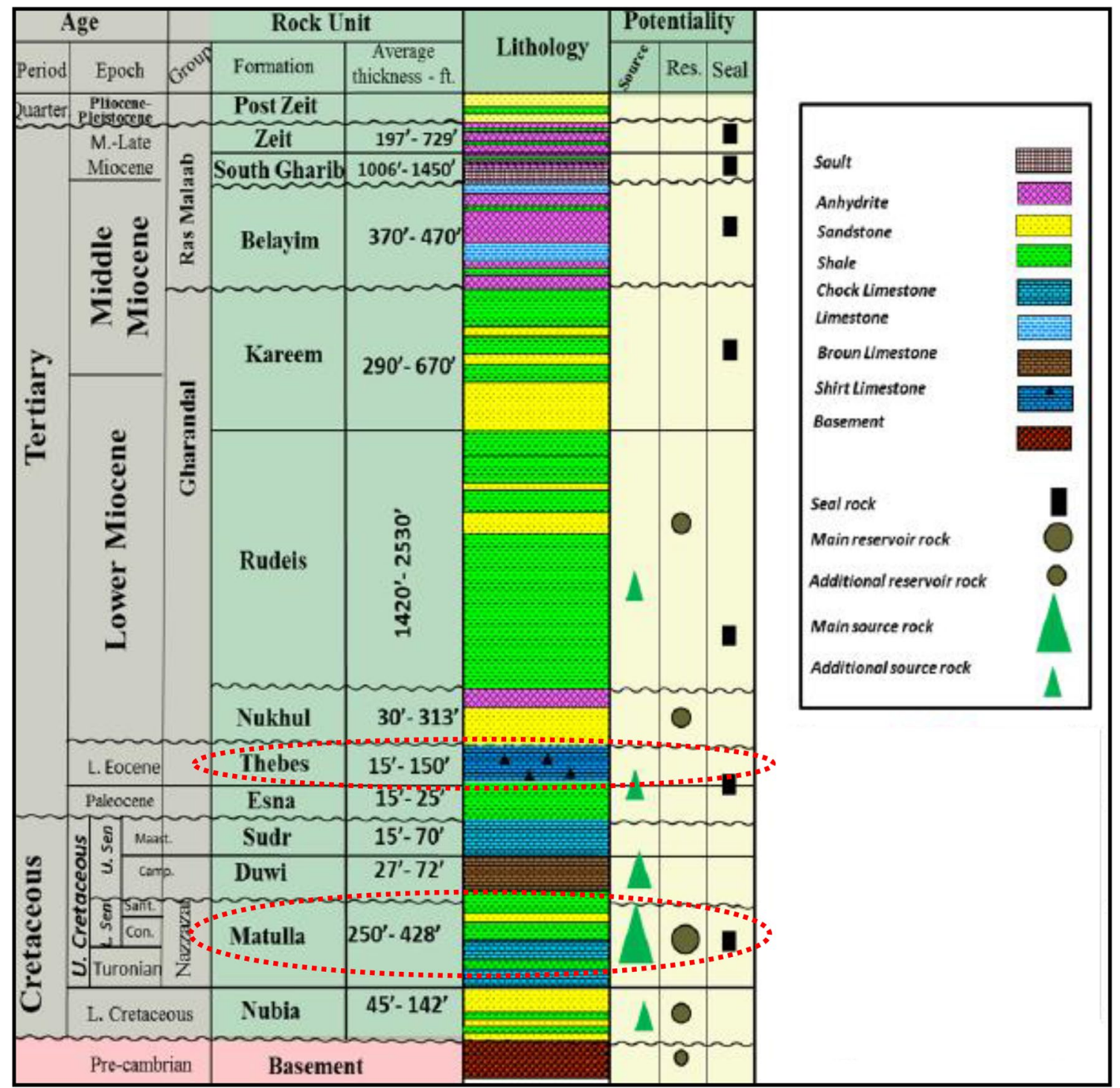

Fig. 2 Stratigraphic column at West Hurghada region comprising Rabeh East field (after Abd El Hafez et al. 2016). Note the stratigraphic position for the examined formations in the present study, which outlined by dotted red polygons

system tracts (HSTs) was due to a significant decline in the holding accommodation space at the final basin filling stage (Elhossainy et al. 2021).

\section{Data and methods}

The available geophysical data in this paper comprise the conventional wireline logs from three examined wells drilled in Rabeh East oil field. These wells are: Rabeh East-8 (RE8), Rabeh East-22 (RE-22) and Rabeh East-25 (RE-25) as presented in Fig. 1b. The mud logs for the three wells are also accessible.

The current work appraises the mud logs with the electric well logs data for the Thebes and Mutulla formations in the three studied wells at Rabeh East field. The three wells' mud logs were initially evaluated qualitatively to identify the prospective hydrocarbon yielding zones within the Thebes and Mutulla formations. After that, the wireline logs for the three wells were analysed using Techlog software to determine the most essential petrophysical parameters for the zones of interest. These parameters contain shale volume (VShale), total porosity $(\Phi T)$, effective porosity $(\Phi \mathrm{E})$, water saturation (Sw) and bulk volume of water (BVW).

\section{Shale volume}

The amount of shale (Vsh) in the studied intervals has been determined using the following equation: 


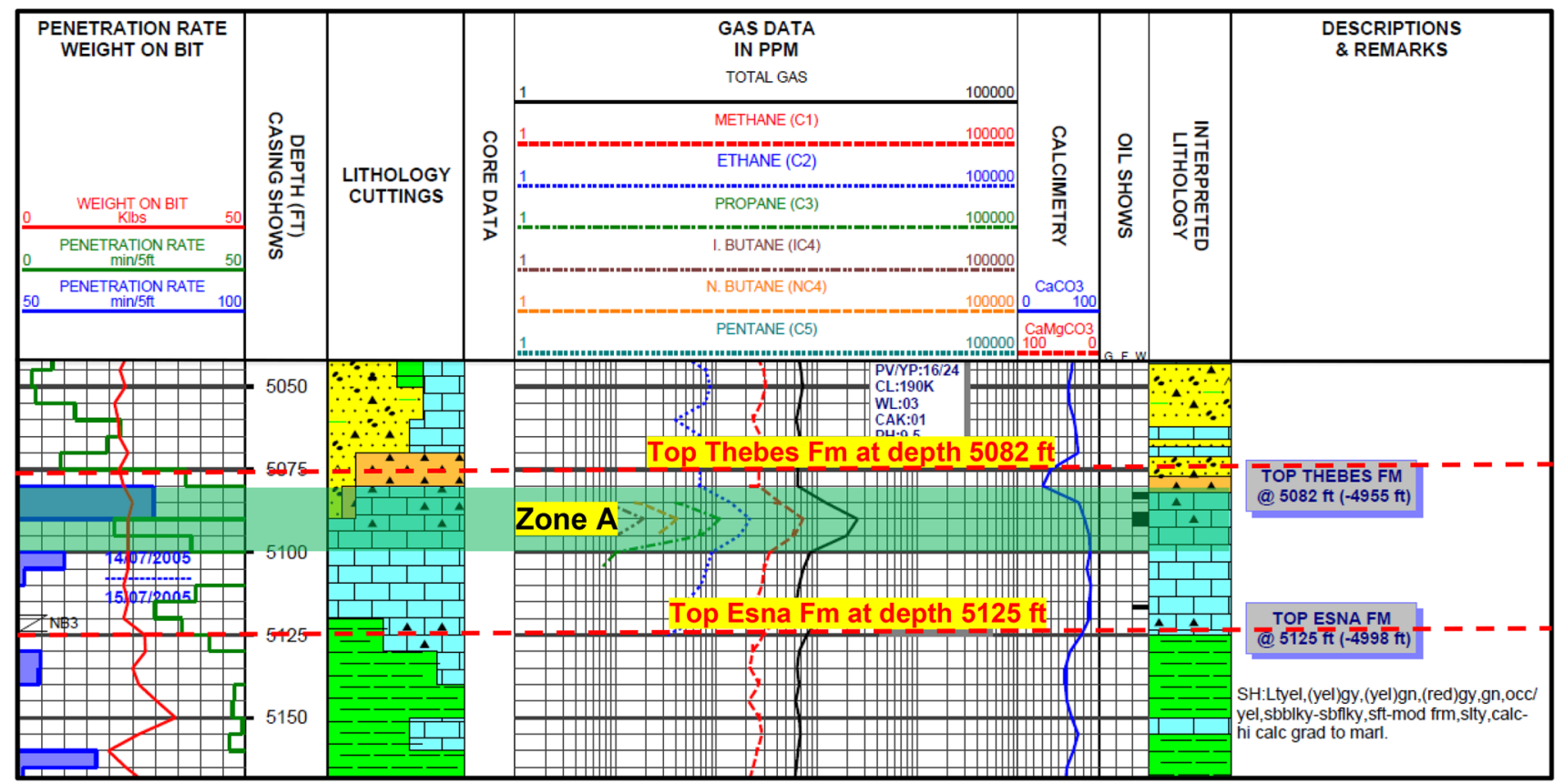

Fig. 3 Mud log displays the Thebes Formation in RE-25 Well. Note the green rectangle outlines the most promising zone within the Thebes Formation (Zone A) between depths 5084 and $5100 \mathrm{ft}$

$\mathbf{V s h}_{(\mathbf{N}-\mathbf{D})}=\left(\boldsymbol{\Phi}_{\mathbf{N}}-\boldsymbol{\Phi}_{\mathbf{D}}\right) /\left(\boldsymbol{\Phi}_{\mathbf{N}(\text { shale })}-\boldsymbol{\Phi}_{\mathbf{D}(\text { shale })}\right)$

where Vsh $_{\text {(N-D) }}$ is the calculated shale volume from neutron and density logs; $\Phi_{\mathrm{N}}$ is the neutron porosity; $\Phi_{\mathrm{D}}$ is the density porosity; $\boldsymbol{\Phi}_{\mathbf{N}}$ (shale) is the neutron porosity of shale; $\boldsymbol{\Phi}_{\mathbf{D} \text { (shale) }}$ is the density porosity of shale.

\section{Total porosity}

Following Asquith and Gibson (1982), total porosity $\left(\phi_{\mathrm{T}}\right)$ was determined from neutron-density logs using the following formula:

$\boldsymbol{\Phi}_{\mathrm{T}}=\left(\boldsymbol{\Phi}_{\mathrm{N}}+\boldsymbol{\Phi}_{\mathrm{D}}\right) / \mathbf{2}$

where $\Phi_{\mathrm{T}}$ is the total porosity; $\Phi_{\mathrm{N}}$ is the neutron porosity; $\Phi_{\mathrm{D}}$ is the density porosity.

\section{Effective porosity}

The effective porosity $\left(\boldsymbol{\phi}_{\mathbf{e}}\right)$ has been measured by the following equation of (Asquith and Gibson 1982):

$\phi_{\mathrm{e}=} \phi_{\mathrm{T} *}(\mathbf{1}-\mathbf{V s h})$

where $\boldsymbol{\phi}_{\mathbf{e}}$ is the effective porosity; $\boldsymbol{\phi}_{\mathrm{T}}$ is the total porosity; $\mathbf{V}_{\mathbf{s h}}$ is the shale volume.

要 KACST

\section{Water saturation}

The water saturation $\left(\mathbf{S}_{\mathbf{w}}\right)$ for the examined zones has been calculated by the Indonesia model (Poupon and Leveaux 1971) from the following equation:

$S_{w}=\left\{\left[\left(\frac{V_{s h}^{2-V s h}}{R_{s h}}\right)^{1 / 2}+\left(\frac{\phi_{e}^{m}}{R_{w}}\right)^{1 / 2}\right]^{2} R_{t}\right\}^{-1 / n}$

where $\mathbf{S}_{\mathbf{w}}$ is the water saturation; $\mathbf{V}_{\mathbf{s h}}$ is the shale volume; $\boldsymbol{\phi}_{\mathbf{e}}$ is the effective porosity; $\mathbf{R}_{\mathbf{s h}}$ is the shale resistivity; $\mathbf{R}_{\mathbf{t}}$ is the deep resistivity; $\mathbf{R}_{\mathbf{w}}$ is the connate water resistivity (set equal to $0.025 \Omega \mathrm{m}^{2} / \mathrm{m}$ according to Ganoub El-Wadi Petroleum Company); $\mathbf{m}$ is the cementation exponent (set equal to 2); $\mathbf{n}$ is the saturation exponent (set equal to 2); $\mathbf{a}$ is the tortuosity factor (set equal to 1 ).

\section{Bulk volume of water}

The bulk volume of water (BVW) has been estimated by applying the following equation of Buckles (1965):

$\mathbf{B V W}=\phi_{\mathbf{e} *} \mathbf{S}_{\mathbf{w}}$ 


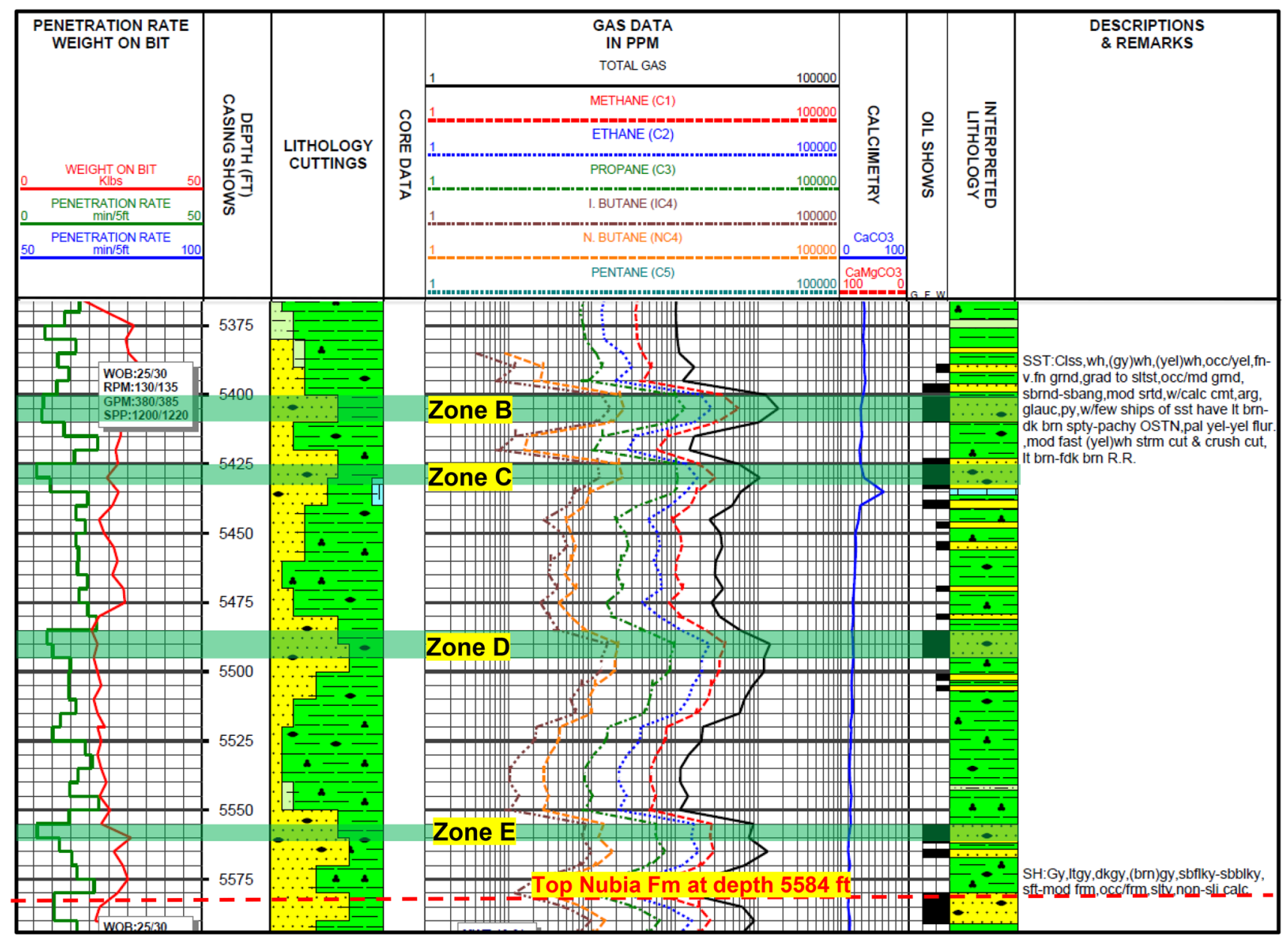

Fig. 4 Mud log shows the Mutulla Formation in RE-25 Well. Note the green rectangles outline the most promising oil-bearing zones between depths: 5403.5 to $5413.5 \mathrm{ft}$ (Zone B), 5425.5 to $5436 \mathrm{ft}$ (Zone C), 5488 to $5498 \mathrm{ft}$ (Zone D) and 5558.5 to $5563.5 \mathrm{ft}$ (Zone E)

where BVW is the bulk volume of water; $\boldsymbol{\phi}_{\mathbf{e}}$ is the effective porosity; $\mathbf{S}_{\mathbf{w}}$ is the water saturation.

\section{Results}

The qualitative examination for Thebes and Mutulla formations in the studied wells (RE-8, RE-22 and RE-25) exposed that RE-25 Well is the only well exhibiting optimistic criteria in five zones for being potential oil reservoirs. The first zone (A) locates between depths 5084 and $5100 \mathrm{ft}$ in the limestone of Thebes Formation (Fig. 5). However, the sandstones of Mutulla Formation have four promising oil-bearing zones (B, C, D and E). These intervals situate between depths: $5403.5-5413.5 \mathrm{ft}$ (Zone B), 5425.5-5436 ft (Zone C), 5488-5498 ft (Zone D) and 5558.5-5563.5 ft (Zone E) as shown in Figs. 6, 7 and 8.

The favourable signals for the recommended five zones comprise the existence of oil shows as well as the high values of the ditch gas analysis opposite to the five examined intervals (Figs. 3 and 4). Also, these intervals display high deep resistivity, which confirm the occurrence of the nonconducive oil in addition to the relatively low gamma-ray approving the little shale content (Figs. 5-8). The sandstones of the examined zones in Mutulla Formation have been defined in the mud log as: colourless, white, greyish white, yellowish white, fine-grained graded to siltstones, occasionally medium-grained, sub-rounded to sub-angular, moderately sorted with calcareous cement, glauconitic and pyritic, brown spotty-patchy oil stain with pale-yellow to yellow fluorescence, moderate fast yellowish white streamcut (Fig. 4).

Consequently, the wireline log suites for the motivating zones (A, B, C, D and E) have been quantifiable appraised. This assessment encompasses the calculations of the vital petrophysical parameters obligatory for judging the potentiality for hydrocarbon reservoirs. These calculations include: shale volume, total porosity, effective porosity, water saturation and bulk volume of water. The results of these parameters for zone A within Thebes Formation in Rabeh East-25

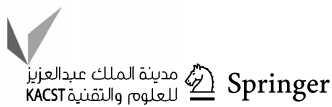




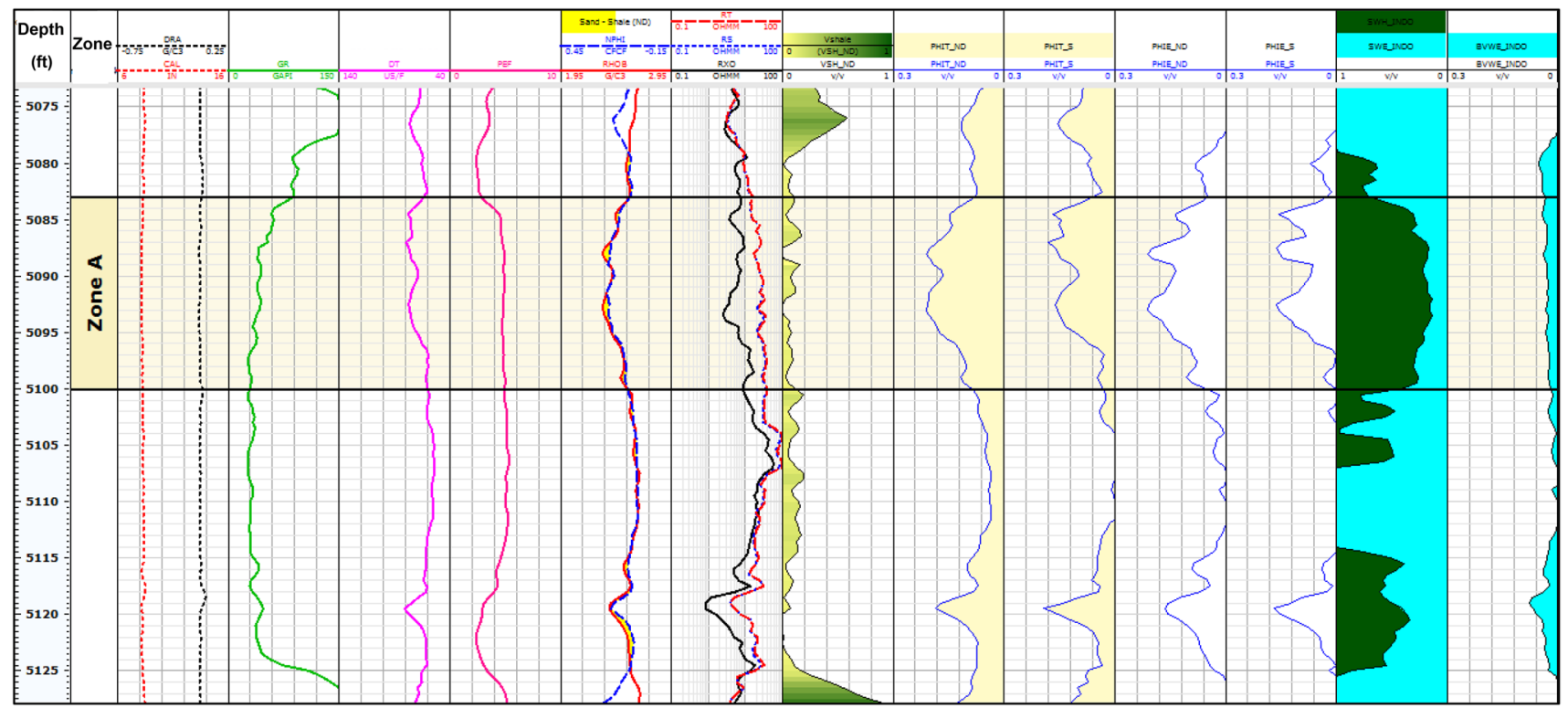

Fig. 5 Petrophysical data with interpretation for the Thebes Formation in RE-25 Well representing the favourable characteristics for oil production in Zone A

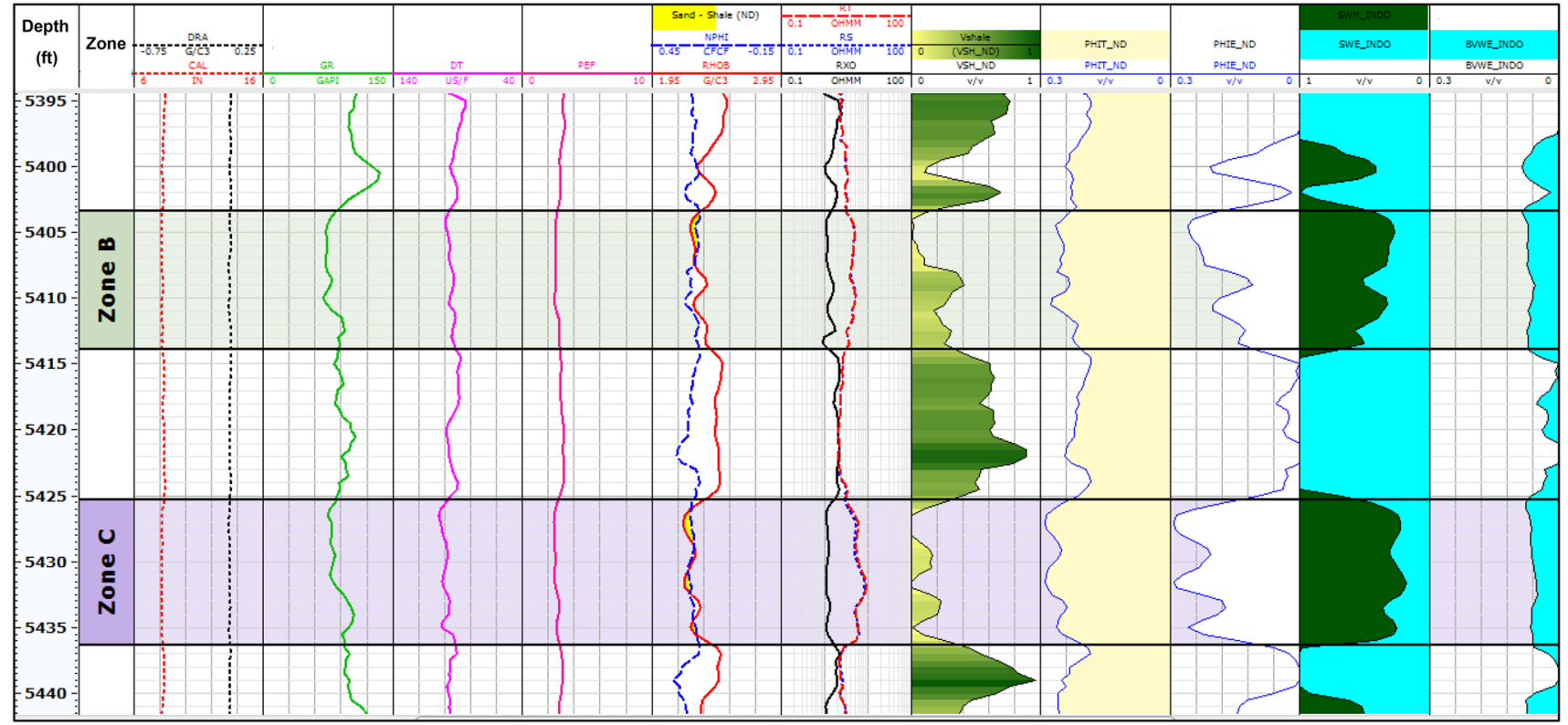

Fig. 6 Petrophysical data with interpretation for the Mutulla Formation in RE-25 Well displaying the positive characteristics for Zones B and C for being oil-bearing intervals

Well are displayed in Table 1, while the calculations for zones B, C, D and E in have been shown in Mutulla Formation, as given in Table 2 .

The neutron-density cross-plot (Schlumberger 1972) for the studied zones shows clearly higher porosity values for zones B, C, D and E within Mutulla Formation (between 20 and 30\%) rather than Zone A in Thebes Formation (only between 10 and 20\%) as shown in Fig. 9.
The calculated amount of shale in the inspected zones as demonstrated in Tables 1 and 2 reveals that the maximum shale volume $(27 \%)$ was documented in Zone D and the minimum value $(7.0 \%)$ was noted in Zone A. However, the estimated total porosity shows that the lowest average value (16\%) was noted in Zone A and the highest total porosity (28\%) was recorded in Zone $\mathrm{E}$ as given in Tables 1 and 2. The measured effective porosity reaches the highest value 


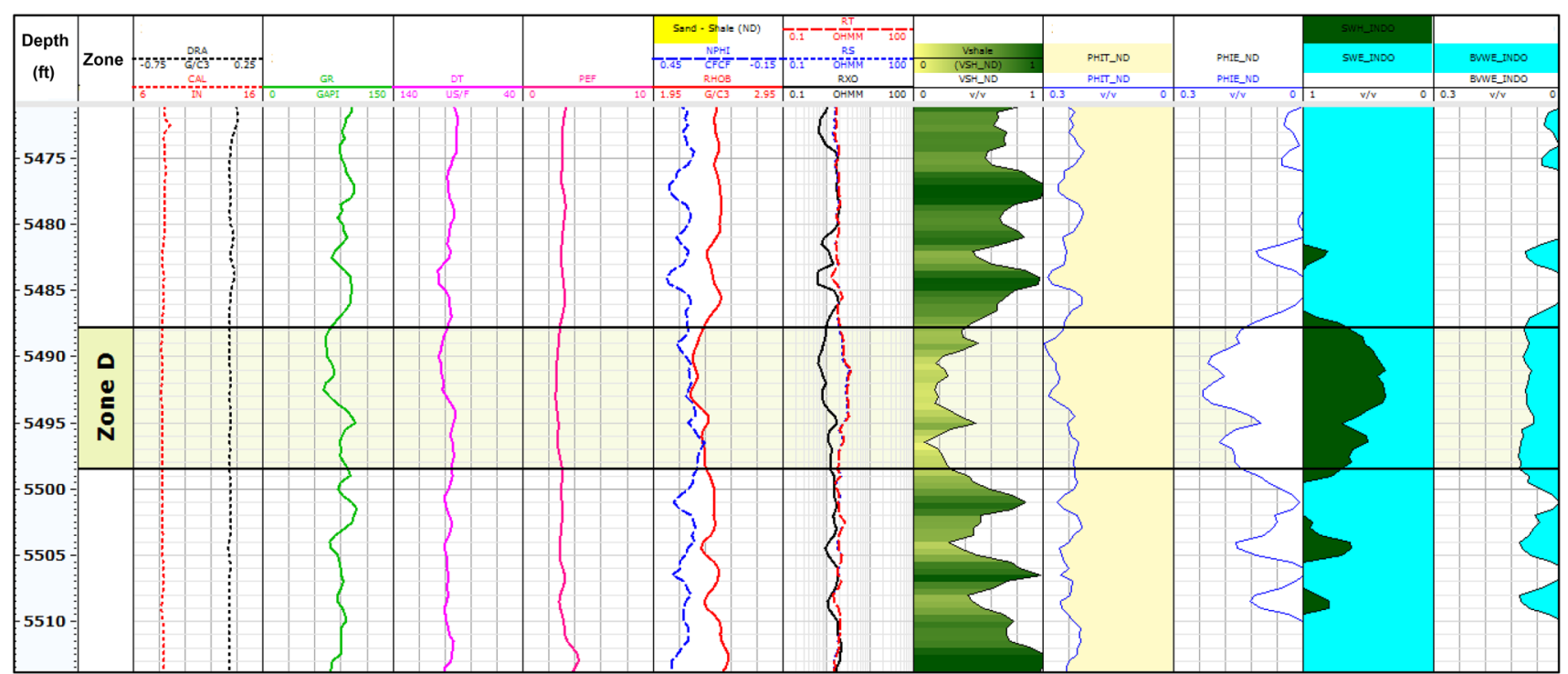

Fig. 7 Petrophysical data with interpretation for the Mutulla Formation in RE-25 Well displaying the optimistic characteristics for oil production in Zone D

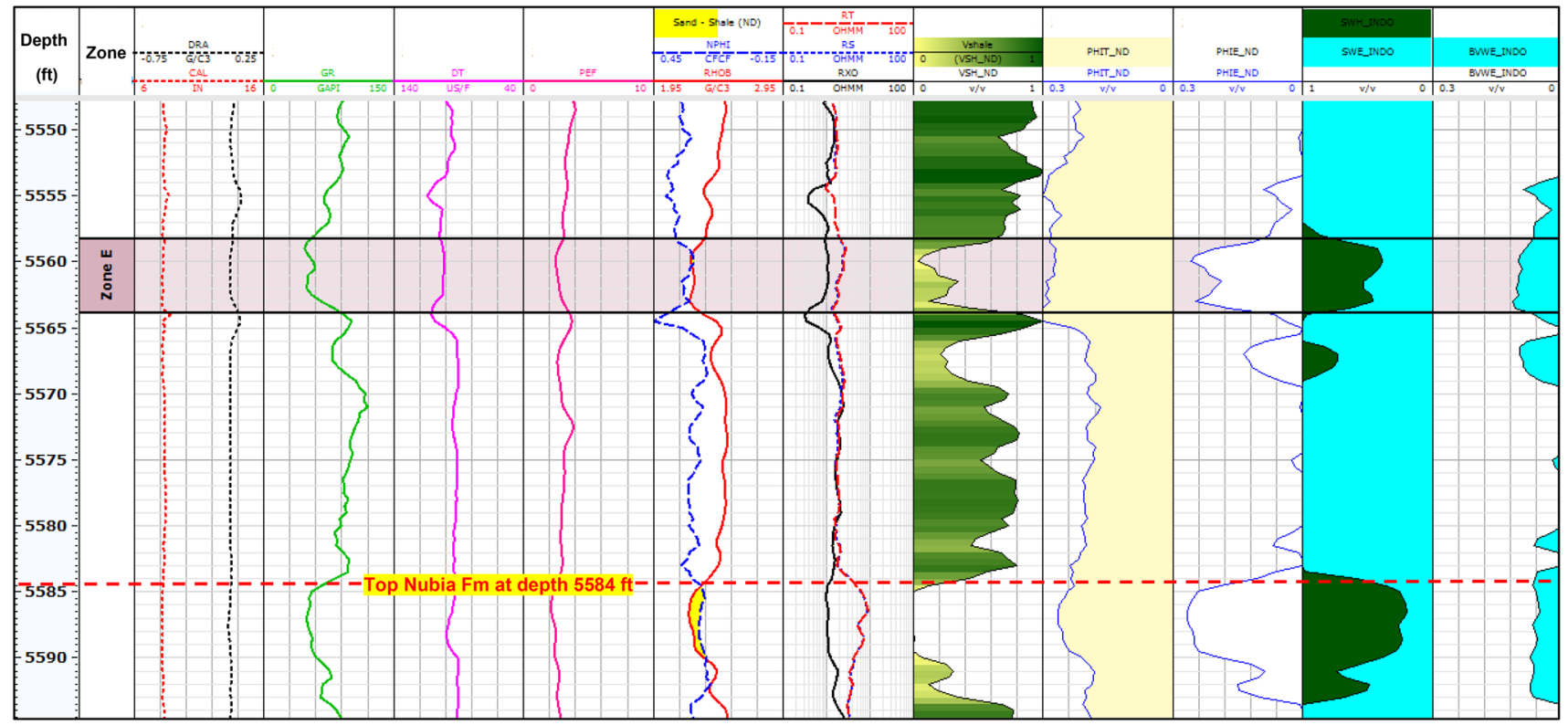

Fig. 8 Petrophysical data with interpretation for the Mutulla Formation in RE-25 Well displaying the bright characteristics of Zone E for being oil-bearing interval

(23\%) that was recorded in Zone C, whereas the lowest value (14\%) was noted in Zone A.

It is worth mentioning that the total and effective porosities for the entire limestone of Zone A have been also calculated using sonic log in order to examine the existence of secondary type of porosity (e.g. fractures, vugs, etc.). This is because the sonic measures only the primary porosity; however, the neutron-density porosity estimates both primary and secondary porosities. The results show that the calculated sonic total porosity (PHIT_S) is $11 \%$ and sonic effective porosity (PHIE_S) is 9\%. Whereas the neutron-density total porosity (PHIT_ND) is $16 \%$, the neutron-density effective porosity (PHIE_ND) is $14 \%$ (Table 1). This notable variance between sonic and neutron-density porosities reflects the existence of a specific type of secondary porosity within Zone A, which increase 


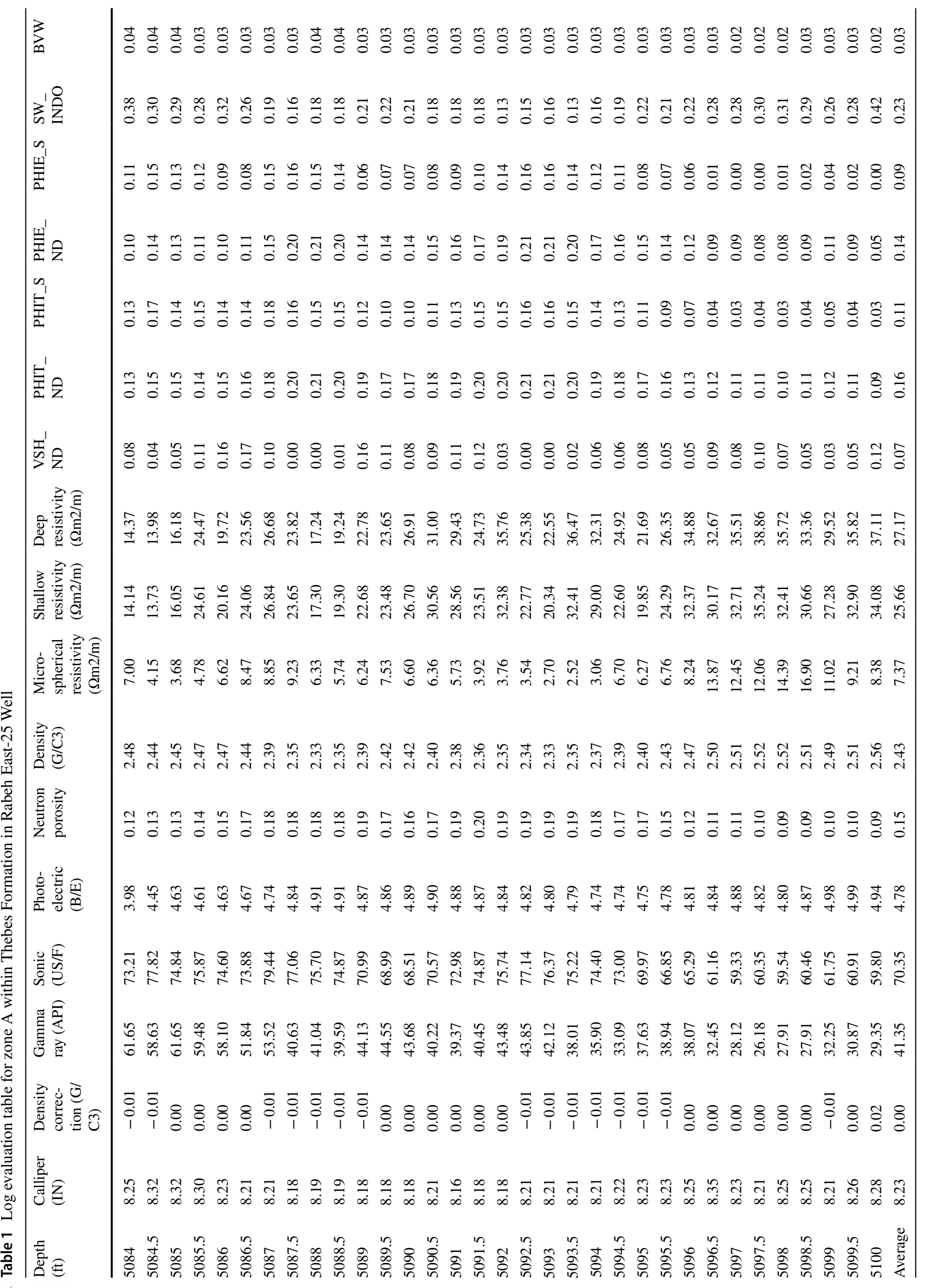




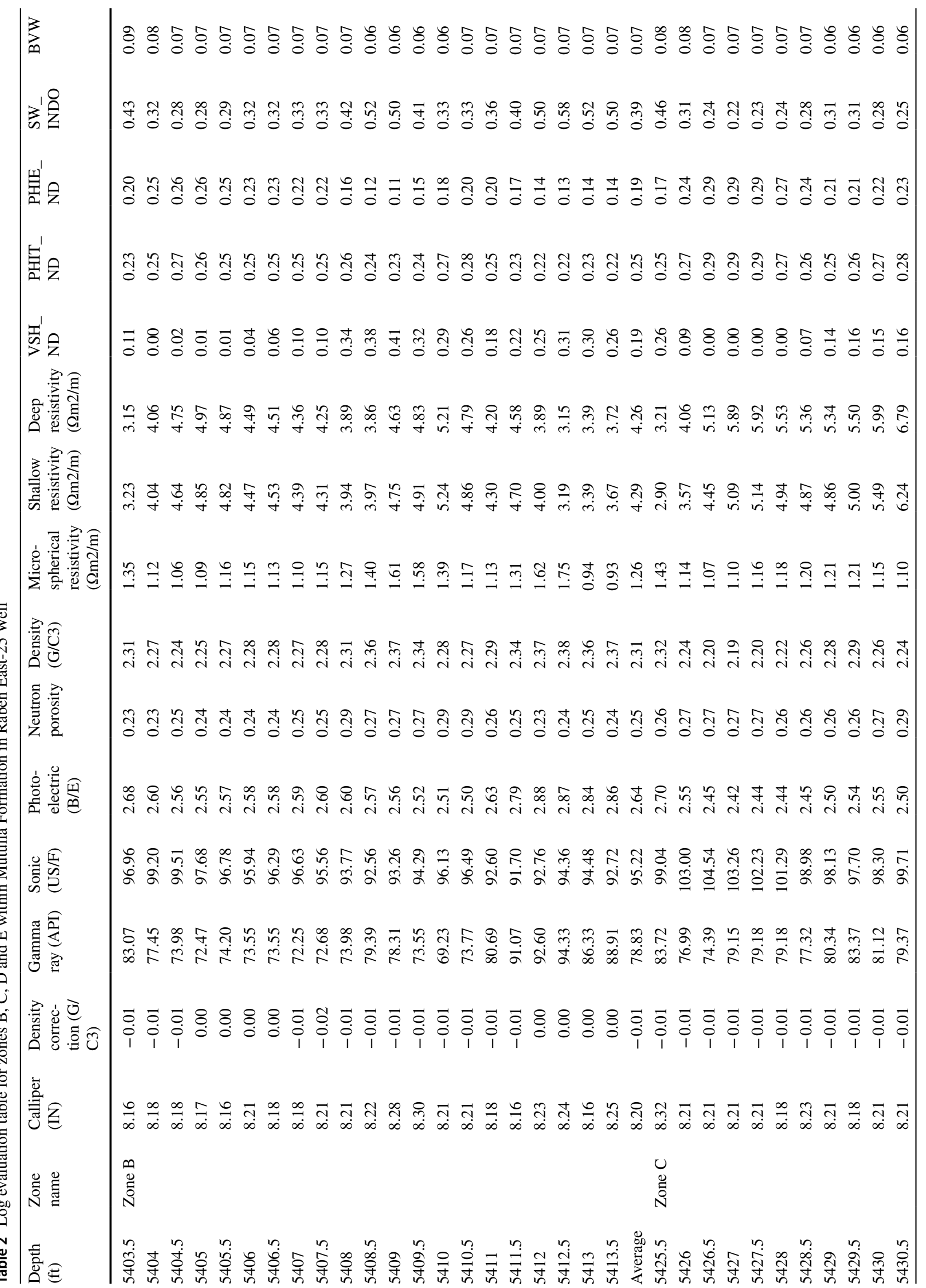




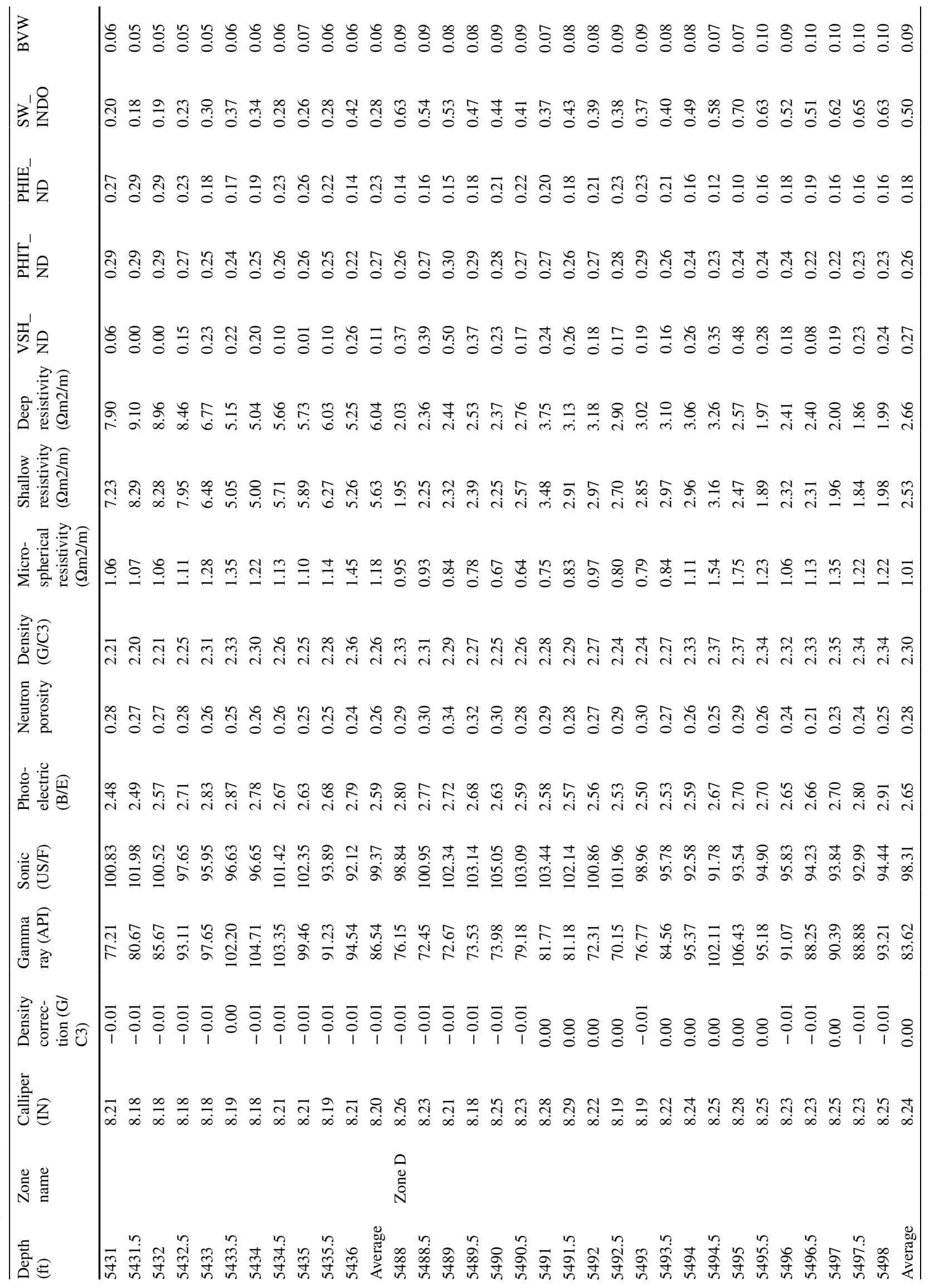




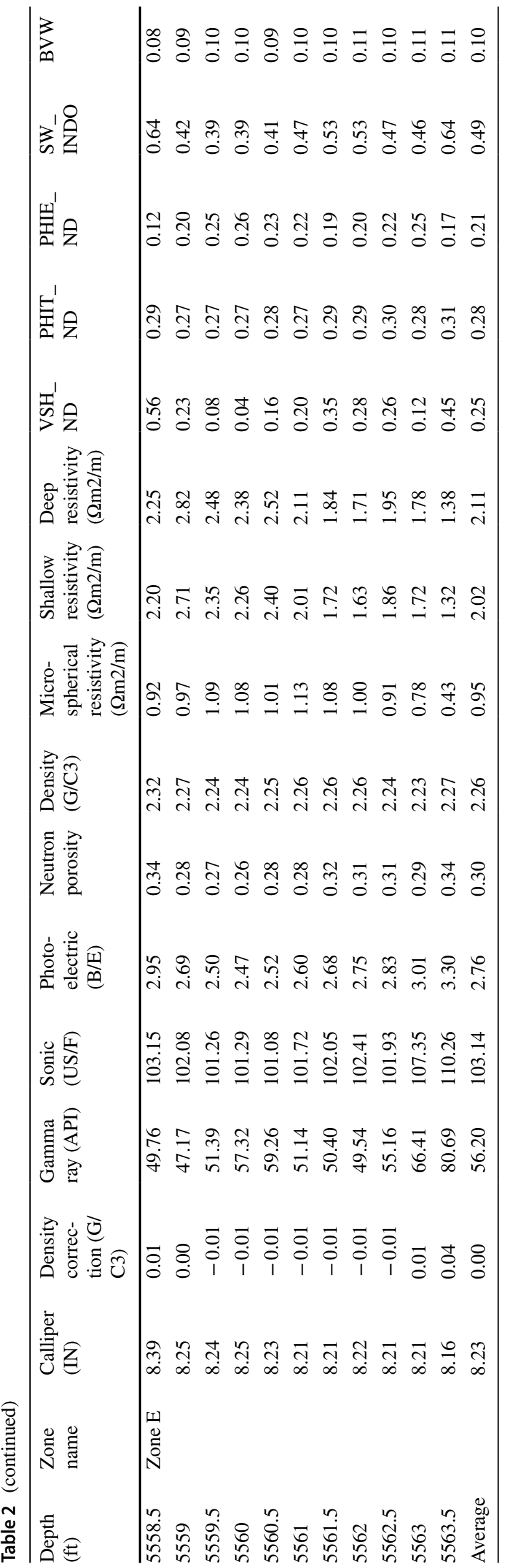

the efficiency of Zone A to be a favourable potential oil reservoir in Rabeh East Field.

The calculated water saturation has been displayed in track twelve in Fig. 5 and track ten in Figs. 6-8, shading with blue colour, while the green colour in the same track refers to the hydrocarbon saturation. The highest average water saturation of $50 \%$ (i.e. the hydrocarbon saturation equals $50 \%$ ) was recorded in Zone D, while water saturation was low in Zone A (23\%) (Tables 1 and 2).

The constructed Pickett plot (Pickett, 1972) for the studied zones shows that most of the plotted points are clustered below line of $\mathrm{Sw}=50 \%$ confirming the hydrocarbon potentiality of these intervals. This reflects that the hydrocarbon saturation in the examined zones expected to be more than $50 \%$ as shown in Fig. 10. This result demonstrates the correctness of the mathematical calculations for the calculated water saturation values as well as the significance of these zones as oil-bearing zones.

The calculated BVW values have been presented in the last track in Figs. 5-8 shading with blue colour. The maximum bulk volume of water (0.10) was documented in Zone $\mathrm{E}$, and the minimum value (0.03) was noted in Zone A (Tables 1 and 2).

The bulk volume of water at the irreducible case in sandstone reservoirs (i.e. expectable to yield water-free oil) depends on the grain size. If sand grains are fine-grained and graded to siltstones as the sand grains in the examined zones within the Mutulla Formation, the BVW values should vary between 0.035 and 0.09 (Asquith and Gibson 1982; Fertl and Vercellino 1978; Asquith 1985). Accordingly, since the BVW values in Zones; B, C and D vary between 0.06 and 0.09 (Table 2), it is expected that these zones will produce oil without water. However, Zone $\mathrm{E}$ that exhibits the highest BVW of 0.10 will produce oil with water.

\section{Conclusions}

The explanation of the well log data for the sandstone of the Mutulla Formation as well as the limestone of the Thebes Formation in Rabeh East Field at Gulf of Suez Basin exposed that these formations are superior oil reservoirs. The comprehensive petrophysical assessment for the well log data of RE-25 Well revealed five oil-bearing zones (A, $\mathrm{B}, \mathrm{C}, \mathrm{D}$ and $\mathrm{E}$ ). These promising intervals represent total net pay thickness of $51.5 \mathrm{ft}$ and display relatively low shale volume (0.07-0.27), high effective porosity $(0.14-0.23)$, low water saturation $(0.23-0.50)$ and low bulk volume of water (0.03-0.10). Zone A represents the promising limestone interval of Thebes Formation with $16 \mathrm{ft}$ thick. This zone includes primary and secondary porosity types supporting the effectiveness of this limestone to be a valuable oil reservoir in the Rabeh East Field. However, the sandstone 


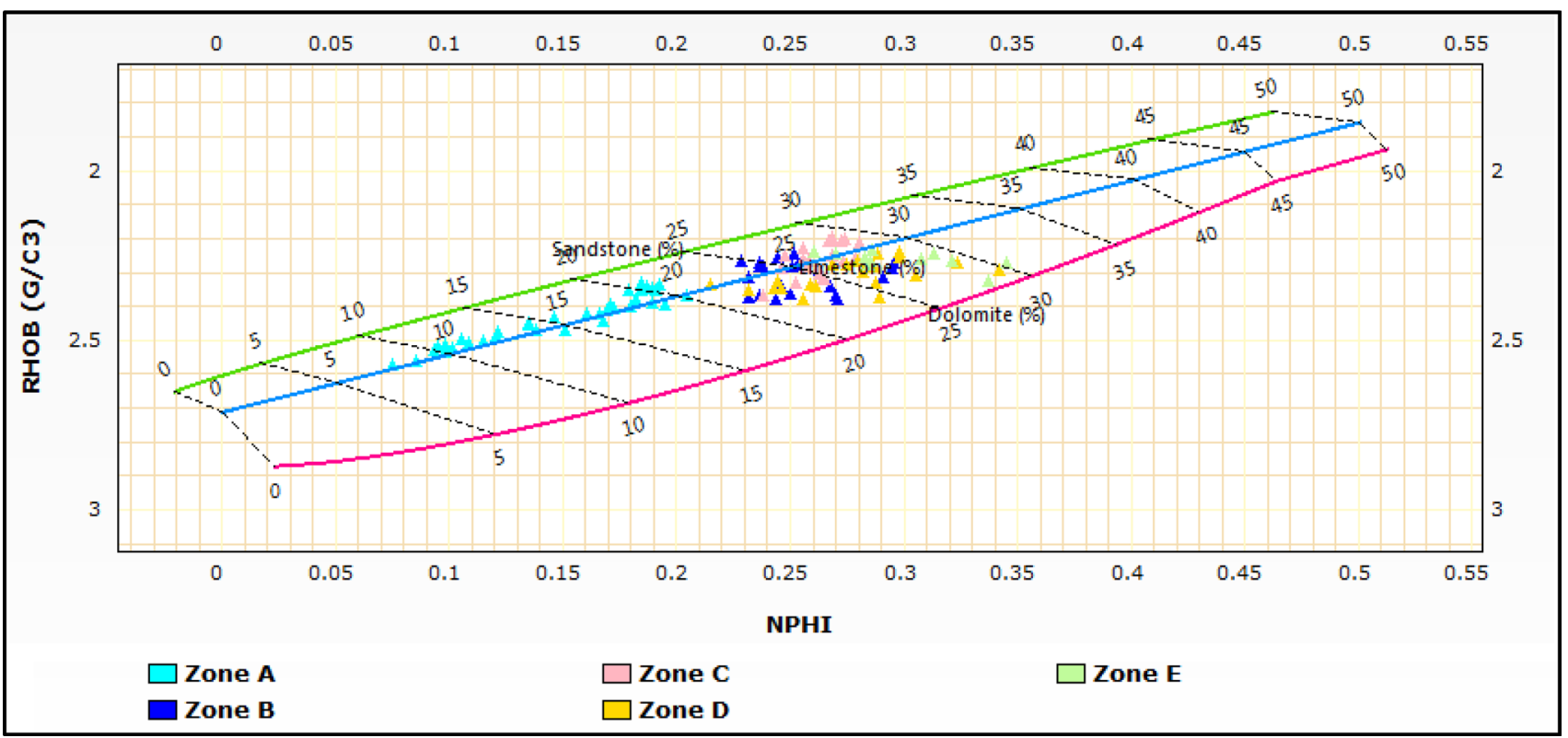

Fig. 9 Neutron-density cross-plot for Zone A in Thebes Formation and Zones B, C, D, E within Mutulla Formation in RE-25 Well

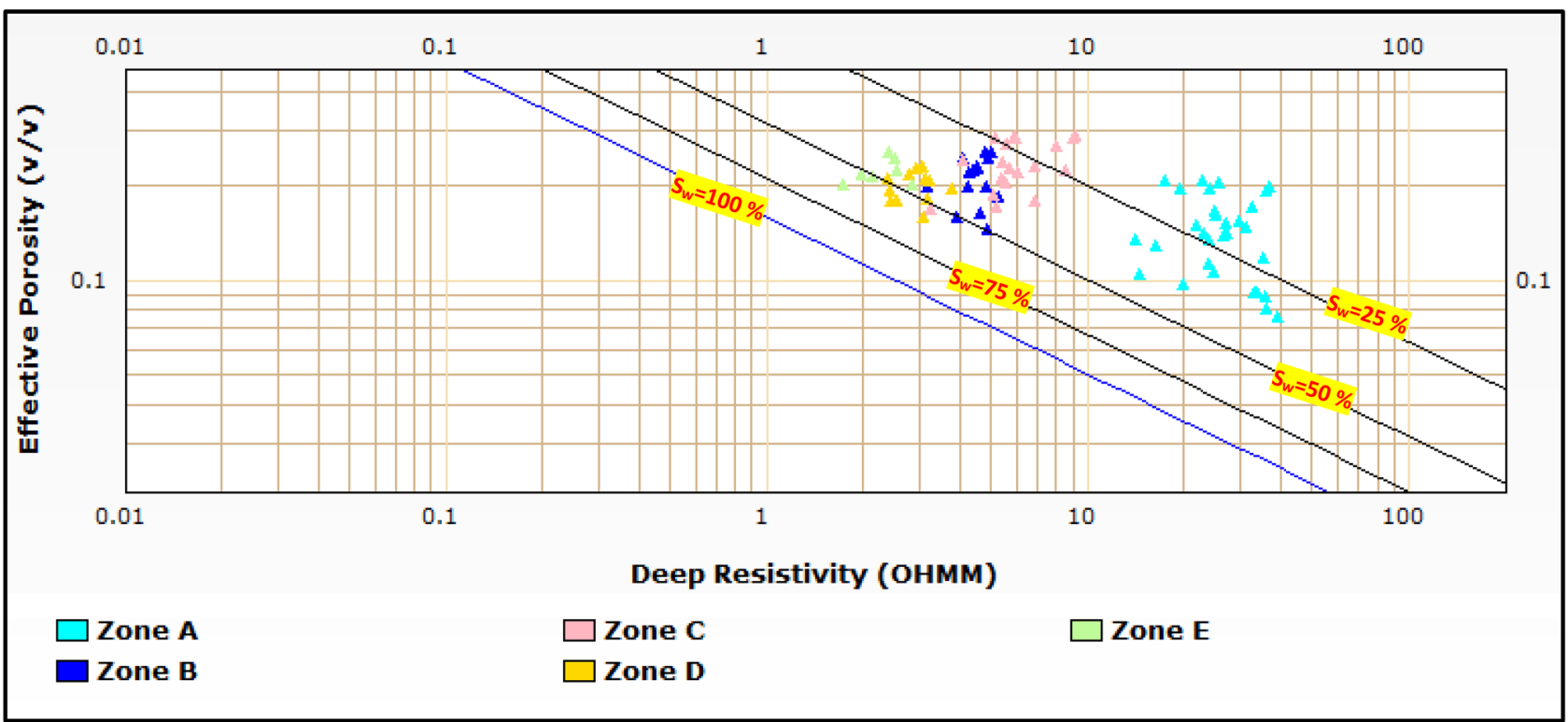

Fig. 10 Pickett cross-plot for the promising Zones A, B, C, D, E in RE-25 Well. Note that the all points locate less than Sw $=75 \%$ line confirming the oil potentiality of these zones

reservoirs within the Mutulla Formation in RE-25 Well represented by zones $\mathrm{B}$ (10 ft thick), C (10.5 ft thick), D (10 ft thick) and E (5 ft thick). Consequently, drilling new wells close to the RE-25 Well in Rabeh East Field is highly indorsed to examine the Mutulla and the Thebes formations as supplementary oil reservoirs beside the main targets including the Nubia, Rudies and Nukhul formations.
Acknowledgements Many thanks for Ganoub El-Wadi Petroleum Company and the Egyptian General Petroleum Corporation (EGPC) for providing the raw geophysical data used in this paper.

Funding The authors received no financial support for the research, authorship, and/or publication of this article. 


\section{Declarations}

Conflict of interest Here, I confirm that there is no conflict of interest.

Ethical approval Hereby, I assure that this paper has not been previously published and the manuscript reflects my own research and analysis in a truthful and complete manner.

Open Access This article is licensed under a Creative Commons Attribution 4.0 International License, which permits use, sharing, adaptation, distribution and reproduction in any medium or format, as long as you give appropriate credit to the original author(s) and the source, provide a link to the Creative Commons licence, and indicate if changes were made. The images or other third party material in this article are included in the article's Creative Commons licence, unless indicated otherwise in a credit line to the material. If material is not included in the article's Creative Commons licence and your intended use is not permitted by statutory regulation or exceeds the permitted use, you will need to obtain permission directly from the copyright holder. To view a copy of this licence, visit http://creativecommons.org/licenses/by/4.0/.

\section{References}

Abd El Hafez N, Abd El Gawad E, Hammed MS, El Naggar HA (2016) Subsurface structural imaging and architecture of pre-rift sediments of west Hurghada district. Egypt Int J Innov Sci Eng Technol 3(12):84-98

Abd-Allah AM, Aal MHA, El-Said MM, El-Naby AA (2014) Structural evolution of the southern transfer zone of the Gulf of Suez rift. Egypt J Afr Earth Sci 96:21-38

Abul Karamat S, and Meshref W (2002) Reverse fault geometry in the Gulf of Suez Rift Basin, Egypt. In International Petroleum Conference and Exhibition (pp 27-30)

Alsharhan AS (2003) Petroleum geology and potential hydrocarbon plays in the Gulf of Suez rift basin. Egypt AAPG Bulletin 87(1):143-180

Asquith G, Gibson C (1982) Basic well log analysis for geologists: methods in Exploration series AAPG, Tulsa, Oklahoma

Asquith GB 1985. Handbook of log evaluation techniques for carbonate reservoirs. Methods in exploration series, Member 5, AAPG, Oklahoma, USA

Atta MA, Shahin AN, Blanchard D, David H (2002) Petroleum potential of the Gemsa Basin, southern Gulf of Suez, Egypt In International Petroleum Conference and Exhibition (pp 27-30)

Bosworth W, Huchon P, McClay K (2005) The red sea and gulf of aden basins. J Afr Earth Sc 43(1-3):334-378

Buckles RS (1965) Correlating and averaging connate water saturation data. J Can Pet Technol 4(1):42-52

Chowdhary LR, Taha S (1987) Geology and habitat of oil in Ras Budran field, Gulf of Suez. Egypt AAPG Bulletin 71(10):1274-1293

EGPC (Egyptian General Petroleum Corporation) (1996) Gulf of Suez oil fields (A comprehensive overview). EGPC, Cairo, Egypt 387 $\mathrm{pp}$

El Nady MM, Ramadan FS, Hammad MM, Lotfy NM (2015) Evaluation of organic matters, hydrocarbon potential and thermal maturity of source rocks based on geochemical and statistical methods: case study of source rocks in Ras Gharib oilfield, central Gulf of Suez. Egypt Egypt J Petroleum 24(2):203-211

El Nady MM, Mohamed NS, Shahin AN (2016) Source-rock potential of Miocene-Paleozeoic sediments in GH-376 oilfield, South
Gulf of Suez. Egypt Energy Sour Part a Recovery Utilization Environ Eff 38(1):100-109

Elhossainy MM, Salman AM, Sarhan MA, Al-Areeq NM, Alrefaee HA (2021) Sequence stratigraphic analysis and depositional evolution of the upper cretaceous deposits in Ras Budran oil field, Gulf of Suez. Egypt Arab J Geosci 14(12):1-13

Fertl WH, Vercellino WC (1978) Predict water cut from well logs, in Practical log analysis, Part 4: Oil and Gas Journal, (May 15, 1978-Sept. 19, 1979)

Moustafa, AR, and Khalil SM (2020) Structural setting and tectonic evolution of the Gulf of Suez, NW Red Sea and Gulf of Aqaba Rift Systems. The geology of Egypt. Springer, Cham. pp 295-342

Patton TL, Moustafa AR, Nelson RA, Abdine SA (1994) Tectonic evolution and structural setting of the Suez rift. In: Landon SM (Ed), Interior Rift Basins. American Association of Petroleum Geologists Memoir. 59 9-55

Peijs JAMM, Bevan TG, Piombino JT (2012) The Gulf of Suez rift basin. In: Roberts Bally (ed) Phanerozoic rift systems and sedimentary basins. Elsevier, Hoboken, pp 165-194

Pickett GR (1972) Practical formation evaluation. Pickett Inc, Golden, Colorado, G.R

Poupon A, Leveaux J (1971) Evaluation of water saturation in shaly formations In SPWLA $12^{\text {th }}$ annual logging symposium Society of Petrophysicists and Well-Log Analysts.

Radwan AE (2021) Modeling pore pressure and fracture pressure using integrated well logging, drilling based interpretations and reservoir data in the giant El Morgan oil field, Gulf of Suez Egypt. J Afr Earth Sci 178:104165

Radwan AE (2021b) Modeling the depositional environment of the sandstone reservoir in the Middle Miocene Sidri Member, Badri Field, Gulf of Suez Basin, Egypt: integration of gamma-ray log patterns and petrographic characteristics of lithology. Nat Resour Res 30(1):431-449

Radwan A, Sen S (2021) Stress path analysis for characterization of in situ stress state and effect of reservoir depletion on present-day stress magnitudes: reservoir geomechanical modeling in the Gulf of Suez Rift Basin Egypt. Nat Resour Res 30(1):463-478

Radwan AE, Kassem AA, Kassem A (2020) Radwany formation: a new formation name for the Early-Middle eocene carbonate sediments of the offshore October oil field, Gulf of Suez: contribution to the eocene sediments in Egypt. Marine Petroleum Geol 116:104304

Radwan AE, Abdelghany WK, Elkhawaga MA (2021) Present-day insitu stresses in Southern Gulf of Suez, Egypt: Insights for stress rotation in an extensional rift basin. J Struct Geol 147:104334

Radwan AE, Rohais S, Chiarella D (2021) Combined stratigraphicstructural play characterization in hydrocarbon exploration: a case study of Middle Miocene sandstones, Gulf of Suez basin, Egypt. J Asian Earth Sci 218:104686

Radwan AE, Trippetta F, Kassem AA, Kania M (2021) Multi-scale characterization of unconventional tight carbonate reservoir: insights from October oil filed. Gulf of Suez rift basin Egypt J Petroleum Sci Eng 197:107968

Sarhan MA (2020) Geophysical appraisal and oil potential for Rudeis Formation at West Hurghada area, southern Gulf of Suez: detection of stratigraphic trap. Arab J Geosci 13(6):1-9

Sarhan MA (2021) Geophysical and hydrocarbon prospect evaluation of Nukhul Formation at Rabeh East oil field, Southern Gulf of Suez Basin, Egypt. J Pet Explor Prod Technol 11(7):2877-2890

Sarhan MA, Basal AMK (2019) Evaluation of Nubia sandstone reservoir as inferred from well logging data interpretation for Rabeh East-25 well, Southwest Gulf of suez, Egypt. J Afr Earth Sci 155:124-136

Sarhan MA, Collier REL, Basal A, Aal MHA (2014) Late Miocene normal faulting beneath the northern Nile delta: NNW propagation of the Gulf of Suez Rift. Arab J Geosci 7(11):4563-4571

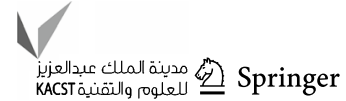


Schlumberger S (1972) Log interpretation/charts. Schlumberger Well Services Inc, Houston

Shaheen AN, Shehab M (1984) Petroleum generation, migration and occurrence in the Gulf of Suez offshore, south Sinai: $7^{\text {th }}$ Egyptian General Petroleum Corporation. In Petroleum Exploration and Production Conference (Vol 1, pp 126-152)

Sultan N (2002) Gulf of Suez/Red sea structural evaluation and hydrocarbon potentiality. In International Petroleum Conference and Exhibit (p 82)
Winn RD Jr, Crevello PD, Bosworth W (2001) Lower miocene nukhul formation, Gebel el Zeit, Egypt: model for structural control on early synrift strata and reservoirs. Gulf of Suez AAPG Bulletin 85(10):1871-1890 